\title{
Indikátor fetisizmus, avagy az elgörbült méterrúd
}

A kutatás-fejlesztés évtizedek óta használt standard indikátorait magától értetődően használjuk az egyes társadalmak és gazdaságok versenyképességének meghatározására. Viszonylag kevesebb figyelem irányul azokra a jelenségekre, amelyek a számok mögött meghúzódnak, és alapvetően meghatározzák az innováció lehetőségeit és gazdasági sikerességét. A hagyományos mutatók mellett találnunk kell olyan más indikátorokat, amelyek segíthetnek a $\mathrm{K}+\mathrm{F}$ és az innovációs folyamatokban való jobb eligazodásban, a gazdasági sikeresség meghatározásában, a fejlesztési programok sikerét vagy éppen sikertelenségét meghatározó mechanizmusok jobb megértésében. Még ennél is fontosabb azoknak a társadalmi folyamatoknak a kiteljesedése és új piaci termékekben való megjelenése, amit ezekkel a mérőszámokkal majd mérni lehet. A tanulmány empirikus kutatási eredmények bemutatásával is igyekszik jelezni, hogy nemcsak a mérési módokon kell változtatnunk, hanem az innováció magyarországi mikro- és makrokörnyezetének együttes átalakítására is szükség van.

Kulcsszavak: innováció, $K+F$, indikátorok, kis-és középvállalkozások, IT-ipar

\section{Szerzői információ:}

\section{Dessewffy Tibor}

Szociológus, az ELTE Szociológia Intézetének docense. Az utóbbi évtizedben több neves külföldi egyetem vendégkutatója, vendégelőadója, illetve ösztöndíjas munkatársa volt. PhD-fokozatát 1996-ban az Amsterdami Egyetemen szerezte meg szociológiából. Tanulmányaival elnyerte a Pro Scientia és az Erdei Ferenc-díjat. Az ELTE-ITHAKA kutatóközpont vezetóje, a 21th Century Trust munkatársa és a European Journal of Cultural Studies címú folyóirat szerkesztốbizottságának tagja. Fốbb érdeklódési területei: az információs társadalom elméletei, a posztmodernitás szociológiai következményei, a technológia fejlódés kulturális kihatásainak vizsgálata, valamint a hétköznapi élet tudásszociológiája. Jelenleg a World Internet Project magyarországi kutatásvezetôje, a Demos Magyarország Alapítvány kuratóriumának elnöke.

E-mail: tibor.dessewffy@ithaka.hu

Ságvári Bence

Szociológus, 1977-ben született Budapesten. Az Eötvös Loránd Tudományegyetem szociológia szakán 2001-ben szerzett diplomát, jelenleg az egyetem doktori iskolájának hallgatója. 2000-ben a londoni University of Westminster, 2004-ben pedig Bloomingtonban az Indiana University ösztöndíjas kutatója volt. 2001 és 2003 között az online piackutatással foglalkozó NRC Kft. kutatási igazgatói tisztét töltötte be. A World Internet Project magyarországi kutatócsoportjának tagja. Egyik alapítója az ELTE Információs Társadalom- és Hálózatkutató Központjának, a Magyar Tudományos Akadémia Regionális Kutatások Központjának kutatója. Kutatási területei közé tartozik az információs technológiák társadalmi-gazdasági hatásainak, továbbá a társadalmi-kulturális értékek és attitúdök gazdasági vonatkozásainak vizsgálata. 2005-tól a kreativitás és az innováció társadalmi meghatározottságát vizsgáló kutatási program egyik vezetôje.

E-mail: bence.sagvari@ithaka.hu 

Dessewffy Tibor - Ságvári Bence

\section{Indikátor fetisizmus, avagy az elgörbült méterrúd}

A kutatás-fejlesztés társadalmi szerepével kapcsolatos közbeszédben meghatározó érvként, szinte magától értetôdően használunk egyes standard indikátorokat. Ugyanakkor e K + F mérốszámok kapcsán egyre inkább egy sajátos paradoxon is felsejlik az információs társadalomra vonatkozó diskurzusban. Szinte valamennyi, a témában jártas szakértő és nagy nemzetközi szervezet egyetért abban, hogy egy adott társadalomnak, illetve gazdaságának az információs forradalomra való felkészültségét többek között a nemzeti jövedelemból a kutatás-fejlesztésre fordított összegek aránya, illetve más kanonizált indikátorok mutatják, ám eközben többnyire figyelmen kívül hagyjuk azt, hogy éppen a $\mathrm{K}+\mathrm{F}$ ráfordítások nyomán elinduló változások és társadalmi átalakulások újraértékelik magát a $\mathrm{K}+\mathrm{F}$ fogalmát, illetve a fogalom tágabb jelentéstartományát is. Ha mélyebben belegondolunk, ez persze korántsem meglepő, hiszen arról van szó, hogy a technológiai fejlesztésekból adódóan napról napra jobban „felpörgô" világunkban egyre nehezebb 5-10 évvel ezelốtti vagy még korábbi fogalmakkal, elméleti konstrukciókkal mérni a technológiai újítások társadalmi-gazdasági hatását.

Nem arról van szó, hogy a hivatalos statisztikák valami egészen másról szólnának, mint ami a valóság maga. Az elmúlt néhány évtized zajos változásai azonban folyamatosan arra kényszerítették az érintetteket, hogy a fejlődéssel lépést tartva minduntalan revízió alá vessék a használatban lévő statisztikai módszereket, vagy éppen új jelenségek, folyamatok nyomon követését integrálják azokba. Ez azonban - jellegéból fakadóan aprólékos és hosszadalmas folyamat, amely csak jelentôs késéssel, és a szükséges kompromisszumok megkötésével képes reagálni a változásokra.

A fentebb említett, nehezen mérhetố innovációk egyik kiemelt területe az ITipar, ahol az elmúlt egy-két évtized nemzetközi tapasztalatait figyelembe véve olyan forradalmi változások következtek be, amelyek némileg árnyaltabbá tették a kutatás-fejlesztésról és az innovációról alkotott korábbi elképzeléseinket.

Tanulmányunkban ennek a problémának egyik sajátos olvasatát próbáljuk meg bemutatni. Az elsố részben a $\mathrm{K}+\mathrm{F}$ és az innováció mérésének nemzetközi és hazai hiányosságaival foglalkozunk, és röviden érintjük azokat az okokat is, amelyek a változtatást szükségessé tették. Ezt követôen - felvetéseinket alátámasztandó megismertetjük az olvasót annak a kutatásunknak néhány idevágó részeredményével, melynek során a sikeres magyarországi informatikai kis- és középvállalkozásokat vizsgáltuk. 


\section{Miért szükséges (részben) újragondolni a jelenlegi indikátorokat?}

A K + F folyamatok átalakulásából következő mérési nehézségek elsôsorban három tényezőre vezethetók vissza.

1. Az elsô ezek közül arra a jelenségre utal, hogy számos esetben olyan paradigmaváltást képviselő újítások jelennek meg (gondoljunk csak az internet különféle felhasználásaira), amelyekkel korábban nem lehetett számolni: az ezek segítségével megjelenô új lehetôségek és folyamatok figyelembevétele a kutatásokban, a minket körülvevố világ megértésében és „megmérésében” óhatatlanul új mérőszámok integrálását teszik szükségessé. Itt elsôsorban olyan indikátorokról van szó, amelyek képesek a $\mathrm{K}+\mathrm{F}$ ráfordítások valódi társadalmi és gazdasági hasznosságát meghatározni.

2. Másrészt, ha az üzleti, gazdasági megtérülés oldaláról közelítünk, számos olyan rendkívül sikeres fejlesztés, innováció van, ahol ugyan megjelenik a szigorú értelemben vett $\mathrm{K}+\mathrm{F}$, de önmagában mégsem ez a legfontosabb tényező, hiszen a technológiai fejlődés tovagyưrúzó hatásainak következtében mára az innováció terepe az ipar területéról erôsen kitolódott a szolgáltató szektor felé, ahol a kreativitás nem annyira múszaki-technológiai, mint inkább szociológiai jellegú. Példaképpen gondolhatunk itt a különböző sikeres internettörténetekre: az Amazon vagy az Ebay.com esetében ugyan van hagyományos (múszaki) értelemben vett fejlesztés, de a gazdasági siker, illetve a társadalmi viszonyokat (át)formáló hatás fóként a felismert fogyasztói igények kielégítéséból származik. De megemlíthetjük itt akár a közelmúlt magyar internetes sikertörténetét, a Wiw (Iwiw) közösségi oldalt is: itt egy olyan sikeres, immár üzletileg is jövedelmezô innovációról van szó, amelynek középpontjában elsôsorban nem valamilyen müszaki-technológiai újítást találunk, hanem egy valós társadalmi igényt felismerô és arra sikeresen válaszoló „humán” innovációt. Más szavakkal: a hagyományos értelemben vett $\mathrm{K}+\mathrm{F}$ ezekben a fejlesztésekben szükséges, de nem elégséges feltétel, sôt megkockáztathatjuk azt is (különösen a shareware, a freeware, illetve a nyitott forráskódú programok sikerére gondolva), hogy számos esetben a szükséges $\mathrm{K}+\mathrm{F}$ bázis túlnyomó része már közkézen forog, és a fogyasztói igények „jókor, jó időben” történő felismerése és igényes kielégítése az, ami a sikertörténeteket igazából útjukra indítja. Ehhez viszont nem kell más, mint egy ötlet, amely a már rendelkezésre álló technológiák, megoldások felhasználásával új termékben vagy szolgáltatásban jelenhet meg, és természetesen szükség van még professzionális menedzselésre is, ami sikeresen képes végigvinni azt az értékesítésig vezetô úton.

3. Végül - a fentiekhez szorosan kapcsolódva - említhetünk egy harmadik, a fejlesztések implementálásával kapcsolatos dimenziót is, amely a $\mathrm{K}+\mathrm{F}$ és az innováció hagyományos mérési módját és a hozzá kapcsolt oksági hatások magyarázó erejét gyengítheti. Ezt lényegében egy esztétikai (esetleg üzleti vagy marketing-) komponensnek nevezhetjük. Itt ismét olyan jelenségról van szó, amely a fogyasztói kapitalizmussal egyidôs, de megítélésünk szerint nem nehéz bebizonyítani, hogy az utóbbi években, a 90-es évek közepe óta egyre erôsebben érvényesül. A késố modern fogyasztói kapitalizmusban megnövekszik a brand, a design, a formatervezés és a hozzá kapcsolódó jelentéstartalmak szerepe. Az, hogy ma egy honlap vagy egy számítógépes kiegészítô mennyire lesz sikeres, nemcsak a benne foglalt $\mathrm{K}+\mathrm{F}$ arányától, hanem az adott „termék” megje- 
lenésétól, vonzóságától vagy a hozzá kapcsolódó tudattartalmak, jelentések szociálpszichológiai hatásától is függ. Ma ez valószínúleg még inkább igaz, mint néhány évvel, évtizeddel korábban volt. Aligha tévedünk nagyot, ha megkockáztatjuk azt is, hogy az eloóttünk álló idôszakban ez a hatás még erôsebb lesz, mint napjainkban. Lehetséges, hogy az iPod-nál számos nagyobb tárolókapacitású hanghordozó létezik, de az általa teremtett divathullámot, „életérzést” meglovagolva mesze megelớzi technológiai értelemben akár hatékonyabb, korszerúbb társait.

Összességében ez a három tényezô veti fel annak szükségességét, hogy felhívjuk a figyelmet a hagyományos $\mathrm{K}+\mathrm{F}$ mérôszámok újragondolására. Természetesen nem arról van szó, hogy a jelenleg használt indikátorokat le kellene cserélnünk. Ugyanakkor az sem kétséges, hogy egyre kevésbé érthetjük meg a minket körülvevố világot akkor, ha (elsősorban az alkalmazott kutatások, kísérleti fejlesztések terén) túlságosan is az „öreg” mutatók védelmező bástyái mögé húzódunk, amelyek egyrészt számos kulcstényezốt hagynak feltáratlanul, másrészt viszont aránytalanul és érdemtelenül nagyítanak fel más - arra talán kevésbé érdemes - jellegzetességeket.

Röviden összefoglalva: a hagyományos, kemény mutatók mellé meg kell találnunk, és ami még ennél is fontosabb, használnunk is kell azokat a többnyire „puha” indikátorokat, amelyek segíthetnek bennünket a $\mathrm{K}+\mathrm{F}$ és az innovációs folyamatokban való jobb eligazodásban, a sikeres vagy éppen sikertelen ötletek, fejlesztések mögött meghúzódó mechanizmusok jobb megértésében.

\section{A K + F mérésére használt módszerek múltia és jelene: a változás szükségességéről}

A K + F mérésének módszertana világszerte próbált és jelenleg is próbál a társadalmi-gazdasági fejlődés következményeihez alkalmazkodni. Ez a munka általában a nagy nemzetközi szervezetek (OECD, Eurostat) keretében zajlik, és a nemzeti adatgyújtố intézmények igyekeznek átvenni az ott megalkotott standard módszereket.

A K + F adatokat Magyarországon 1953 óta gyújtik, 1969-tól kezdôdôen ezt a munkát a Központi Statisztikai Hivatalon (KSH) belül végzik. Az adatfelvételbe bevont szervezetek száma az elmúlt évtizedek során folyamatosan bóvült. Az 1950-es évekhez képest, amikor még csak az állami kutatóintézetek vettek részt az adatgyújtésben, jelentős változások következtek be. A vizsgált körbe sorra kerültek bele más költségvetési és nem állami K + F múhelyek. A betéti társaságokra, illetve a nonprofit szervezetekre csak 2000 óta terjed ki az adatgyújtés.

Magyarországon a nemzetközi standardokhoz való alkalmazkodás folyamata 1988tól indult meg, kezdetben még csak az UNESCO részére történt mérések terén, majd 1991-tól az OECD, késóbb pedig az Eurostat módszereihez alkalmazkodva. Az 1963-as év fontos mérföldkố a $\mathrm{K}+\mathrm{F}$ mérésének nemzetközi történetében. Ekkor készült el az OECD elsô, standard módszertani normarendszerként szolgáló kiadványa, az ún. Frascati kézikönyv. A K + F számítása és a fogalmak definíciói máig ezen, illetve a kiadvány legújabb, 2002-ben kiadott és jelentősen átdolgozott változatán alapulnak. Ez utóbbi már kifejezetten a tudás-alapú gazdaság igényeinek próbál megfelelni. 
Ez a kiadvány ugyanakkor csupán egy azok közül a módszertani útmutatók közül, amelyek az OECD keretében elkészültek. A „trilógia” (a Frascati-család) csak két másik kézikönyvvel kiegészülve tekinthető teljesnek. Ezek egyike az 1995-ben megjelent Canberra kézikönyv (Canberra Manual), amely a tudomány és a technológia területének humáneróforrás-oldalát elemezte, és ezzel kapcsolatban fogalmazott meg alapvető módszertani standardokat. A másik munka, az Oslo kézikönyv (Oslo Manual) témánk szempontjából különös jelentôségú, hiszen ez az innovációs folyamatok leírásához és elemzéséhez ad útmutatót. Ebben a formájában ez az elsô olyan nemzetközi forrás, amely komplex formában próbálja meg áttekinteni a kérdést. A kézikönyv 2005-ben megjelent harmadik kiadásának külön értéke, hogy - szakítva a korábbi gyakorlattal röviden kitér a nem technológiai innováció folyamataira is, bár eközben továbbra is következetesen a technológiai értelemben vett új termékek és eljárások állnak vizsgálata középpontjában.

A statisztikai adatgyújtés Magyarországon a szervezetek vonatkozásában jelenleg teljes körú, kiterjed valamennyi kutatást és fejlesztést fő- vagy melléktevékenységként folytató szervezetre, függetlenül annak tulajdonformájától és fớ tevékenységi területétól.

$\mathrm{Az}$ adatgyújtések során ugyanakkor két fontos szempont egyidejü érvényesítése nehezíti a helyzetet. Az egyik az összehasonlíthatóság biztosítása, idóbeli és nemzetközi tekintetben egyaránt (ebból fakadóan bizonyos fokú állandóságra van szükség), míg a másik a kutatási-fejlesztési tevékenység tartalmában, feltételrendszerében bekövetkezett módosulásokhoz történô folyamatos igazodás, ami viszont - az elôzoóvel éppen ellentétben - rugalmas változtatásokat követel(ne) meg.

Miközben a KSH az adatgyújtés során a jelenleg használatos és a nemzetközi szakirodalomban is általánosan elfogadott fogalmakat és kategóriákat használja, ezzel némileg ellentmondóan egy kiadványában maga a hivatal jelzi, hogy a magyar kutatásifejlesztési statisztikában használt, utoljára 1979-ben kiadott statisztikai fogalmak is módosításra és kiegészítésre szorulnak. ${ }^{1}$

A K + F mérés fejlődését az $O E C D$ és az Eurostat, illetve a magyar Kutatási és Technológiai Alap elvárásai határozzák meg. Ezek feladatként írják elố a technológiai fizetési mérleg, illetve a (kormányzati) K + F kutatások társadalmi és gazdasági célok szerinti bontásának vizsgálatát. Az adatgyújtés ugyanakkor nem terjed ki a kutatási eredmények felhasználhatóságára, annak módjaira és lehetôségeire vagy az ezzel kapcsolatos bárminemú mérésekre. A KSH erre vonatkozó közleményében, sốt a pénzügyi fogalmak 5 oldalas taglalásában kizárólag a költségek és a források felsorolása található meg, és a hazai módszertani kánonban nemcsak bevételekról nincsen szó, de egyáltalán nem szerepel a kutatási eredmények értékesítésének, illetve hasznosulásának semmilyen dimenziója sem.

Ugyanakkor ez a módszertan láthatólag nem ad lehetôséget sem ágazat, sem kutatási hely alapján bizonyos kutatási formák azonosítására (például az egyetemisták otthoni innovációinak jól ismert esetében, lásd például Bill Gates történetét), továbbá nem képes kezelni a hosszabb ideig tartó kutatást, majd terjedelmes publikációkat nem igény-

\footnotetext{
${ }^{1} \mathrm{KSH}, 2004,7$.
} 
lő ,instant” innovációkat, ${ }^{2}$ és gyakorlatilag nem feltételezi azt sem, hogy elsődleges célként, kifejezetten az üzleti bevételt megjelölve, egyáltalán lehetséges a fejlesztés és a fejlődés.

A Manuel Castells által is leírt informacionalizmus logikáját egyre inkább követő globális kapitalizmus vagy a Thomas Friedman által nemrégiben az úgynevezett „, harmadik konvergenciával” jellemzett „lapos Föld” korszakában (illetve az ahhoz való alkalmazkodás elôsegítésének érdekében) különösen fontos - de figyelmen kívül hagyott - dimenzió lenne az implementálás képességének önálló mérése, vagyis az alkalmazott kutatásból az „alkalmazás” önálló és kitüntetett jelentôségú sikerfaktorként való elismerése (Castells, 2000; Friedman, 2006).

Ehhez képest a Magyarországon jelenleg használt módszertan nem látszik alkalmasnak a hazai kutatást és fejlesztést támogató stratégiák megalapozásához szükséges adatok elốteremtésére, és összességében is igen távol áll az innováció lélektanától.

E tanulmány keretein belül természetesen nem vállalkozhatunk egy új, az elóbbi felvetéseket operacionalizáló K + F és innovációs statisztikai indikátorrendszer kimunkálására. Mindazonáltal jelezni kívánjuk, hogy épp a társadalmi technológiai változások miatt lenne szükség olyan mérốszámok kialakítására, amelyek inkább figyelembe veszik a paradigmaváltást, a fogyasztói, a piaci, az üzleti sikert, vagy éppen az esztétikai elismerést. Más szavakkal: a kutatás-fejlesztés hagyományos indikátorai (a ráfordításoknak a GDP-hez viszonyított százalékos aránya, a kutatók és a kutatási témák, illetve a végeredménynek tekintett találmányok, szabadalmak, védjegyek, publikációk stb. száma) helyett, illetve mellett a valódi társadalmi hatásokat jobban figyelembe vevő fogalmi keretek és ennek megfeleltethetố mérốszámok kidolgozása lenne szükséges. Ez nemcsak Magyarország számára lenne különösen időszerú, hanem európai kontextusban is fontos kihívást jelent. Ezen a téren a lokális (országos) kísérletek mindaddig nem hozhatnak igazi áttörést, amíg a K + F (és kisebb mértékben az innovációs) mérôszámok - érthetố módon - a nemzetközi és uniós szabványokat követik.

A lisszaboni folyamat eredménytelenségét hagyományosan az előzőekben említett $\mathrm{K}$ + F mérószámokkal (is) szokás mérni. Az Unió globális pozícióvesztéséról, versenyképességének csökkenéséról szóló információk szinte már-már közhelyszámba mennek. Ugyanakkor hipotézisszerúen megfogalmazhatjuk azt is, hogy amennyiben modernizálnánk a mérési módszereket, azaz némi revízió, átalakítás és kiegészítés eredményeképpen bekövetkezne egy szemléletváltás az alkalmazott $\mathrm{K}+\mathrm{F}$ és innovációs indikátorok területén, az Európai Unió jelenlegi teljesítménye az információs társadalom megvalósulása, a tudásalapú társadalom megteremtése tekintetében talán még aggasztóbb képet mutatna. A valóságos helyzet elfedése azonban nyilvánvalóan nem lehet érdeke Európának.

\section{Egy kutatás első tanulságai}

Az eddig megfogalmazott aggodalmak és felvetések munkáltak bennünk akkor is, amikor egy évvel ezelótt elindítottuk a sikeres üzleti stratégiákkal foglalkozó kutatásunkat. Ennek keretében azokat a hazai kis- és középvállalkozásokat vizsgáltuk, ame-

${ }^{2}$ Ezeknek egyik szemléletes gyưjjtóhelye elérhető a http://www.milliondollarhomepage.com/ címen. 
lyek az informatika területén egyrészt saját kutatási, fejlesztési és innovációs, illetve kreatív teljesítményük révén váltak sikeressé, másrészt erre alapozva eredményesen tudtak a hazai közegból kilépve a globális gazdaság hálózataihoz kapcsolódni.

Jelen tanulmányunknak nem témája a kutatás eredményeinek részletes bemutatása, azonban mindenképpen fontosnak tartunk megemlíteni néhány olyan tényezót, amelyek a $\mathrm{K}+\mathrm{F}$ teljesítmény mérésének problematikájához kapcsolódnak, immár a konkrét folyamat oldaláról. Vagyis miközben fontosnak tartanánk új típusú $\mathrm{K}+\mathrm{F}$ mérószám(ok) és fogalmi keretek kidolgozását, még ennél is fontosabbnak tartjuk azoknak a társadalmi folyamatoknak a kiteljesedését és új piaci termékekben való megjelenését, amelyeket ezekkel a mérószámokkal majdan mérni lehetne.

Ezt azonban kétségtelenül számos akadály hátráltatja. Az alábbiakban néhány olyan negatív jellegzetességet emelünk ki, amelyek a fentiekkel összhangban jól jellemzik a magyarországi informatikai kis- és középvállalkozások helyzetét.

\section{A "buherakorszak" vége}

Kétségtelen, hogy a nagyvállalati szférán kívül megszületô, a hatalmas megaprojektekhez képest majdnem a semmiból létrejövô „instant innovációknak” az elmúlt idôszakban kiváló terepet kínáltak a számítástechnikához és az internethez kapcsolódó iparágak. Az ugyan várható, hogy az első „forradalmi lendület” után valamelyest talán csökken a magányos feltalálók, egyetemi csoporttársak „heurékaeffektusainak” jelentôsége, reményeink szerint azonban ez a szektor továbbra is fontos területe marad a fejlödésnek.

Amikor az információs társadalom megvalósításának terén Európa globális lemaradásáról beszélünk, akkor tudomásul kell vennünk azt a tényt, hogy a már említett negatív folyamatok halmozottan érvényesek Magyarországra. Egy nemrégiben a kreatív gazdaságról publikált tanulmányunkban, ${ }^{3}$ amely az Európai Unió országainak felkészültségét makroszinten elemezte, rámutattunk arra, hogy a hagyományos K + F mérôszámokban Magyarország Európán belüli pozíciója meglehetôsen gyenge, és ebból fakadóan sajnos azt sem feltételezhetjük, hogy hazánk tágabban értelmezett, a társadalmi hatásokra inkább fókuszáló $\mathrm{K}+\mathrm{F}$ és innovációs pozíciói ennél érezhetően jobbak lennének.

Sokan persze máshogyan látják a helyzetet: a hazai IT-vállalkozások genezistörténetét feldolgozó - egyelôre nem túl bőséges - irodalomban gyakran találkozhatunk a buhera dicséretével: ezzel arra a mentális és technológiai tudáskészletre utalnak a szerzók, amely jelentôs számú olyan vállalkozónak volt sajátja, akik a késő Kádár-korszak felemás gazdaságában, hiányos piaci szerveződéseiben „edződtek”. Ez a habitus a 80-as évek végén és a 90-es évek elején a magyar vállalkozók egy részének olyan tudást biztosított, ami az ebben az idôszakban kialakuló nemzetközi piacon jól hasznosítva akár komoly versenyelónyt is jelenthetett. (Jó példa erre a magyar IT-ipar két „zászlóshajója”, a Kürt és a Graphisoft.)

\footnotetext{
${ }^{3}$ Ságvári-Dessewffy, 2006.
} 
Látnunk kell azonban, hogy a 90-es évek közepétól ez az egyedi előny, vagy legalábbis ennek technológiai-kognitív része egyre inkább elenyészni látszik. Az a kreatív bátorság és a sajátos társadalmi-gazdasági környezetben megszerezhetố tudás, ami abból fakadt, hogy „a Trabantot egy drótkefével is meg lehet javítani”, hasznos lehetett a hôskorban, a C64-ek, a ZX Spectrumok és a Bécsból alkatrészenként behozott és összeszerelt IBM XT számítógépek korában, de ez a fegyvertár jellegéból fakadóan nem igazán alkalmas önmaga megújítására, és egyre kevésbé lesz hadra fogható a 21. század információs társadalmában, ahol lassan már az autószerelố múhelyekben is csak a hibajelző elektronikus berendezések kódjainak a kiolvasásához és a kapott utasítások mechanikus végrehajtásához kell érteni.

Ezt a tételt támasztja alá az általunk megkérdezett IT-cégvezetốk véleménye is, akik többé-kevésbé egybehangzóan állították, hogy nincs (már) olyan, a magyar vállalatokra, a hazai humán tốkére jellemzó sajátosság, amely pozitív értelemben kiemelné a hazai cégeket a nemzetközi mezônyben, és ezáltal speciális versenyelőnyhöz juttatná óket. Kétségtelen, hogy ez a jelenség 1-2 évtizeddel korábban még létezett, ám mára a „szegény ember vízzel foóz” receptjéból táplálkozó kreativitás eltúnt a vállalkozói étlapról.

Mindennek azért van jelentôsége, mert a globális verseny játékszabályai jelentôs átalakuláson mentek keresztül. Az ötlet már csak az elsó lépés, a hangsúly egyre inkább azokra a területekre (például menedzsment, design, marketing, értékesítés) tevơdött át, ahol a magyar vállalatok és vállalkozók sokszor érzékelhetố hátrányban vannak.

\section{A vállalkozói kultúra hiányosságai, a "rutininnováció" előtérbe kerülése}

Az IT-ipar innovációs folyamatainak egyik meglepó sajátossága, hogy a kutatás és a fejlesztés területét - szemben a Daniel Bell által jósolt fejleményekkel (Bell, 2001) nem monopolizálják a multinacionális óriáscégek. Miközben ezek közül némelyeknek az innovációs teljesítménye lenyúgöző, nem lehet elsiklani afölött, hogy például a személyi számítógépek, az első operációs rendszerek, az internetes keresôprogramok és az olyan sikeres felhasználások, mint például a fájlcseréló programok nem a több száz millió dolláros költségvetésú kutatólaboratóriumokban, hanem egyetemisták íróasztalánál, garázsokban és kollégiumi szobákban születtek (Noughton, 1999). Ahogy korábban megfogalmaztuk, szembeötlő sajátossága az információs kornak, hogy a kialakulásához vezető forradalom ugyan a hagyományos gazdasági struktúráktól elválaszthatatlanul, ám lényegében azoknak az intézményeitól függetlenül, mintegy azok „árnyékában” ment végbe (Dessewffy, 2002). A napjainkban sikeres vállalkozások jelentôs része (például Microsoft, Google, Skype stb.) is a klasszikus, hagyományos vállalati „establishment” keretein kívül bontogatta szárnyait, majd többnyire egy-egy új iparágat, szolgáltatási területet létrehozva, vagy egy már létezốt „a feje tetejére állítva” vált emblematikus gazdasági szereplővé.

A kreatív korral foglalkozó, már idézett korábbi tanulmányunk másik fontos üzenete az volt, hogy egy társadalom aktuális értékrendje, ha ellentmondásban van a posztindusztriális átalakulás értékvilágával, hosszabb távon komoly akadályokat je- 
lent(het) a gazdasági fejlődés számára. Adataink tanúsága szerint Magyarország ezen a téren is komoly terheket cipel magával.

Ennek egyik kézzelfogható elemeként a hazai közegben komoly hátrányt jelent, hogy változatlanul hiányzik vagy csak nyomokban van jelen az a vállalkozói kultúra, az a sikerre orientált attitúd, ami a „K + F” és az innováció általunk kívánatosnak tartott megközelítése értelmében egy technológiai újításból sikeres terméket képes létrehozni. Nyilvánvaló, hogy az üzleti sikernek csak egy részeleme a vállalkozói kultúra, hiszen a lehetôségeket elsősorban a piac, a jogi-szabályozási környezet, a tóke jelenléte, a munkaerố szakmai felkészültsége stb. határozza meg. Ugyanakkor nem vitás, hogy a vállalkozói kultúra bizonyos kulcselemei, mint például a kockázatvállalásra való hajlandóság, a teljesítmény tisztelete, a siker társadalmi elismerése vagy a konformitás elutasítása mind-mind olyan alapvetó értékek, amelyeknek össztársadalmi szinten is meg kell jelenniük, mert csak ezekból nóhetnek ki azok a sikeres vállalkozók, akik mindezeket az értékeket koncentráltan hordozzák magukban, és teljesítményükkel érzékelhetố módon járulnak hozzá a gazdasági fejlódéshez.

Itt nyilvánvalóan rendkívül bonyolult és komplex feladatról van szó, amelyhez hozzátartozik az is, hogy a jelenség közvetlen eszközökkel nem, vagy csak nagyon korlátozottan befolyásolható. A probléma jobb megértéséhez az egyik lehetséges megközelítési mód a vállalkozói létforma első igazi teoretikusa, Schumpeter gondolatainak az újragondolása és a mai helyzetre való alkalmazása lehet.

A vállalkozói kultúrának, a vállalkozó figurájának a tanulmányozása viszonylag mostoha terepe volt a tudománynak, napjainkra azonban az egyik meghatározó kutatási területté nốtte ki magát, miután egyre többen ismerték fel jelentôségét a gazdasági fejlôdésben. Sốt, ma már az üzleti iskolák, az MBA-(Master of Business Administration) fokozatot nyújtó business schoolok kötelező tananyaga, ami egyben jól jelzi azt is, hogy az ezzel kapcsolatos ismereteket tanítható és fejleszthetô, egyszerú rutinkészségek alapjának tekintik. Ennek kétségkívül van létjogosultsága, azonban éppen a globális gazdasági fejlődés, a piacok liberalizálása és a multinacionális vállalatok tevékenysége hozta felszínre az eltérô társadalmi-kulturális környezetek és értékrendszerek alapvető fontosságát egy-egy ország vállalkozási kultúrájában.

Mint közismert, Schumpeter így írt: „Mit tettek (a vállalkozók)? Nem halmoztak föl semmiféle javakat, nem hoztak létre eredeti termelési eszközöket, viszont a régitól eltéró módon, megfelelóbben, elónyösebben használták fel a létezố termelési eszközöket. Új kombinációkat hoztak létre."4

Schumpeternél a gazdasági fejlődés elsô számú tényezôje a vállalkozó, a kitüntetett folyamat pedig nem más, mint maga az innováció, ami számos formában megvalósulhat. Innovációnak tekinthetô többek között valamilyen új termék bevezetése, új gyártási mód bevezetése, új piac megnyitása, új nyersanyag vagy félkész termék forrásának megszerzése és az iparági átszervezés is. Ez az innováció töri meg azután a statikus, egyensúlyi helyzetet, és elindítja a magasabb szintú fejlődést. A vállalkozó által véghezvitt innovációt Schumpeter olyan kreatív alkotási folyamatnak tartotta, ahol a hangsúly a hagyományos korlátok áttörésén, meghaladásán van. Így alapvető fontosságúnak te-

${ }^{4}$ Az idézet forrása: Mintzberg-Ahlstrand-Lampel, 2005, 145. 
kintette a vállalkozónak a status quo megváltoztatására törekvő, „forradalmi” és „,bátor” karakterét. Számos olyan pszichológiai és szociológiai tényezốt vett számításba, amelyek alátámaszthatták a vállalkozó személyiségének kiemelkedố szerepét és egyedi minôségét.

Közismert az is, hogy a 20. század első felében Schumpeter ennek az egyéni kreativitáshoz kapcsolódó vállalkozói értékvilágnak és viselkedésnek a hanyatlását vetítette elốre, a nagy szervezetek rutinizált innovációs folyamatainak eloótérbe kerülésére számítva. Mivel számára ez a vállalkozói kultúra egyben a kapitalizmus alapvetô mozgatórugóját is jelentette, annak eltúnésével magának a kapitalizmusnak a hanyatlását vizionálta. Ez - mint az utóbbi néhány évtized jól bizonyítja - korántsem következett be, azonban napjainkban az innovációs folyamatok két módozata jól láthatóan elvált egymástól. Röviden arról van szó, hogy a világgazdaságban végbemenő változások, a nagy (multinacionális) vállalatok szerepének növekedése és az egyre kiélezettebbé váló verseny a vállalaton belüli innovációs folyamatok erôteljes rutinizálódását eredményezte. Ennek hátterében elsôsorban a biztos, tervezhetố üzletmenet számára a legnagyobb ellenségnek tekintett bizonytalanság mértékének csökkentése húzódik meg. Ez azonban kétélú folyamat: a kiszámítható profitszempontok az innováció „leszabályozását”, kemény korlátok közé kényszerítését kívánják meg, ugyanakkor nem nehéz belátnunk, hogy ez éppen attól fosztja meg a vállalatot, hogy ráleljen azokra az ,aranytojást tojó tyúknak" is tekinthető felfedezésekre, amelyek csak olyan vállalati innovációs környezetben születhetnek meg, ahol elsôsorban nem a menedzseri és költségvetési szempontok érvényesülnek. ${ }^{5}$ Ennek a problémának a felismerését jelzi többek között a Google cég vállalati politikája is, ahol a kutatással és fejlesztéssel foglalkozó alkalmazottak számára lehetővé tették, hogy munkaidejük meghatározott részében az óket érdeklő témákkal foglalkozzanak. Ilyenkor természetesen nem a rövid távú profitcélok az elsốdlegesek, hanem a jövố forradalmi (és ezáltal nagy bevétellel is kecsegtetô) termékeinek és szolgáltatásainak az ígérete.

Magyarország esetében ismert, hogy a $\mathrm{K}+\mathrm{F}$ ráfordítások nagyobb részben állami, kisebb részben vállalati forrásból származnak. Amellett, hogy ennek az aránynak ${ }^{6}-\mathrm{a}$ fejlett gazdaságok példáiból kiindulva - éppen fordítottnak kéne lennie, a hazai helyzetet tovább árnyalja, hogy a vállalati $\mathrm{K}+\mathrm{F}$ meghatározó része csupán néhány (külföldi tulajdonú) nagyvállalathoz kapcsolódik (például a gyógyszeriparban). Amennyiben csak az IT területét vizsgáljuk, a helyzet talán még több aggodalomra ad okot, hiszen a nagyvállalati szektorban egy-két pozitív kivételtól eltekintve (például Microsoft, Ericsson, Nokia, SAP) lényegében nem folyik $\mathrm{K}+\mathrm{F}$ tevékenység. Sót, a magyarországi vállalatok elsôsorban az adott globális cég $\mathrm{K}+\mathrm{F}$ stratégiájának egyes részelemeit hajtják csak végre, tehát egyértelmúen a fent említett rutinizált $\mathrm{K}+\mathrm{F}$-ról van szó.

Mindezekból kiindulva különösen fontosnak látjuk a hazai informatikai kis- és középvállalatok (KKV-k) szerepét, amelyek betölthetnék azt az úrt, amelyet a nagyvállalatok által szabadon hagyott innovációs terep jelent számukra. Kutatásaink eddigi

\footnotetext{
${ }^{5}$ Lásd erról bôvebben: Baumol, 2002.

${ }^{6}$ A vállalati $\mathrm{K}+\mathrm{F}$ múhelyek részesedése az összes $\mathrm{K}+\mathrm{F}$ ráfordításból $38 \%$, ami messze elmarad a fejlett európai országok $50-80 \%$ közötti értékeitól. Az ezer alkalmazottra eső vállalati kutatók számának aránya Magyarországon csak 40\%-a az EU átlagának (KSH, 2005).
} 
eredményei alapján azonban be kell látnunk, hogy a nemzetközileg is sikeres vállalkozások száma és jelentôsége még korántsem érte el azt a „kritikus tömeget”, ami nemzetközi szinten is biztosíthatná elismerésüket. Az általunk megkérdezett vállalatvezetók a sikertelenség okaként általában a magyar környezet speciális hátrányait emelték ki. Elsốsorban a piac méretére, valamint a kreatív vállalkozási tevékenység számára elớnytelen gondolkodásbeli, attitúdbeli jellemzókre tértek ki, amelyek alapvetóen meghatározhatják a vállalkozások külsố környezetét, végeredményben pedig a vállalkozás sikerességét. Az adminisztratív környezet bürokratikus és a paternalista szemléletmódra visszavezethető nehézkességére itt most részletesen nem térünk ki, de kétségtelen, hogy ezeket sem lehet figyelmen kívül hagyni.

Végül még a vállalkozói (és a szélesebb társadalmi) kultúra egyik fontos hiányosságáról is említést kell tennünk. Ez nem más, mint az együttmúködés, a kölcsönös bizalmon és kölcsönös érdekeken nyugvó kooperáció szinte teljes hiánya. Széleskörúen elfogadott nézet, hogy a tudásalapú gazdaság fejlődésében - amelyben az IT-ipar kulcsszerepet tölt be - alapvetố fontosságú, hogy nemcsak a gazdasági szférán belül, hanem a gazdasági szereplók és az egyetemek, illetve más kutatóintézetek, továbbá kisebb mértékben a gazdaság és a politikai, valamint a civil szféra között is együttmúködési kapcsolatok alakuljanak ki. Ilyen jellegú, jól müködő, az egyszerú próbálkozás szintjén nem megrekedő kapcsolatokkal a vizsgált vállalatok körében lényegében nem találkoztunk. A szférák egymás iránti érdeklődése minimális, egymásról alkotott képüket számos elôítélet és prekoncepció határozza meg, holott köztudomású, hogy a térbeli koncentráció, a klaszterek létrejötte ilyen együttmúködési kapcsolatok nélkül elképzelhetetlen.

\section{Befejezés helyett}

Örömteli tény, hogy az érintett magyarországi szereplók gondolkodásában, a stratégiai tervekben és fejlesztési koncepciókban az általunk vázolt problémák mind nagyobb intenzitással jelennek meg a helyzetelemzés szintjén és a lehetséges beavatkozási területek megjelölésében. Igaz, hogy ez egyelôre többnyire csak papíron, sokszor pedig csupán a jól hangzó kijelentésekben, viszonylag kevés kézzelfogható eredménnyel nyilvánul meg, de érvényesülni kezd az a jogos igény, hogy a kutatás-fejlesztés az általa indukált gazdasági fejlődésen keresztül végsố soron a társadalom, az emberek jólétét kell, hogy szolgálja. Itt és most nem feladatunk, hogy az alap- és az alkalmazott kutatások sokszor mondvacsinált szembeállításában az egyik vagy a másik mellett, vagy valamelyik ellen foglaljunk állást. Az azonban bizonyos, hogy a kettốt világosan el kell különíteni egymástól, és az alkalmazott kutatások esetében - fóleg a hatékonyság mérésében - alkalmazni kell azokat a módszertani megfontolásokat, amelyeket írásunkban is áttekintettünk. A hatékonyság elemzése és mérése mindamellett csak a feladat elsố részét jelenti. Az információs társadalom kiteljesedése során, a globális szereposztásnál Magyarország nem számíthat túl sok jóra abban az esetben, ha nem lesz képes az említett problémák orvoslására, az innováció mikro- és makrokörnyezetének együttes megváltoztatására. 


\section{Irodalom}

A K + F statisztika módszertana (2004). Statisztikai Módszertani Füzetek, 42. Budapest: KSH.

Kutatás és fejlesztés 2004 (2005). Budapest: KSH.

Baumol, William J. (2002): The Free-Market Innovation Machine. Princeton University Press.

Bell, D. (1973): The Coming of Post-Industrial Society: A venture is Social Forecasting. Basic Books.

Canberra Manual. The Measurement of Scientific and Technological Activities. OECD. www.oecd.org/dataoecd/34/0/2096025.pdf

Castells, Manuel (2000): The Rise of the Network Society. Oxford: Blackwell Publishing.

Dessewffy T. (2002): Az árnyékvilág szociológiája. Információs Társadalom, 2002 (1).

Frascati Manual. Proposed Standard Practice for Surveys on Research and Experimental Development. OECD. www1.oecd.org/publications/e-book/9202081E.PDF

Friedman, Thomas L. (2006): És mégis lapos a Föld. Budapest: HVG Kiadó.

Mintzberg, Henry - Ahlstrand, Bruce - Lampe, Joseph (2005): Stratégiai sæafari. Útbaigazítás a stratégiai menedzsmentben. Budapest: HVG Kiadó.

Noughton, J. (1999): A Brief History of the Future. London: Weidendfeld and Nicholson.

Oslo Manual. The Measurement of Scientific and Technological Activities. OECD. www.oecd.org/dataoecd/35/61/2367580.pdf

Ságvári Bence - Dessewffy Tibor (2006): A kreatív gazdaságról. Magyarország és Európa a kreativ korban. Budapest: Demos, (A tanulmány angol fordításban a http://www.demos.hu/index.php?name $=\mathrm{OE}-$ DocManager $\&$ file $=$ download $\& i d=36 \&$ keret $=\mathrm{N} \&$ showheader $=\mathrm{N}$ címen érhetố el.) 